\title{
CADANGAN, KEHILANGAN, DAN AKUMULASI KARBON PADA PERKEBUNAN KELAPA SAWIT DI LAHAN GAMBUT TROPIKA ${ }^{1)}$
}

\author{
Maswar $^{2)}$, Oteng Haridjaja ${ }^{3)}$, Supiandi Sabiham ${ }^{3)}$, Meine van Noordwijk ${ }^{4)}$
}

\begin{abstract}
Peat land conversion to oil palm plantation affects carbon stocks and can change a net sink of atmospheric carbon (C) into a net source. The influence of location, type of peat, drainage practices and fertilization is insufficiently known. A study was conducted in West Aceh from May 2008 until October 2009 in oil palm plantations of various age. Carbon stocks and $\mathrm{C}$ loss were calculated from data of bulk density (BD), ash content, carbon content, and peat depth. A new method for $\mathrm{C}$ loss estimates using ash as internal tracer was developed and tested. Peat land characteristics after drainage and conversion to oil palm plantation were investigated by field observation and laboratory analysis of peat soil samples in the laboratory. Results showed that: 1) Distance from the drain influences the rates of: a) water table depth, b) subsidence, with rates of 1,1 to $9,2 \mathrm{~cm} /$ year and $22.67-57.23 \%$ influence of $\mathrm{C}$ loss, and c) soil carbon loss. 2) Ash content and bulk density of the peat are related, indicating the partial loss of soil C during compaction. 3) An "internal tracer" estimate of peat $\mathrm{C}$ loss yields estimates of $\mathrm{CO}_{2}$ flux up to $48 \mathrm{t} \mathrm{CO}_{2}$-eq ha- $\mathrm{y}^{-1}$ for young oil palm, highly correlated with measured rates of subsidence of the surface and water table depth. 4) Patterns of weight loss of surface litter, measured in litter bags, respond to inherent quality $(\mathrm{C} / \mathrm{N})$. Some data for oil palm on shallow peat suggest that a net sink for $\mathrm{C}$ can be maintained under such conditions.
\end{abstract}

\section{Key words: Carbon stock, carbon loss, carbon accumulation, oil palm, tropical peat.}

1) Bagian dari disertasi Sekolah Pascasarjana, Institut Pertanian Bogor

2) Mahasiswa S.3 pada Program Studi Ilmu Tanah, Sekolah Pascasarjana, Institut Pertanian Bogor

3) Departemen Ilmu Tanah dan Sumberdaya Lahan, Fakultas Pertanian, Institut Pertanian Bogor

4) Principal soil ecologist in World Agroforestry Center (ICRAF)

\section{PENDAHULUAN}

Saat ini hubungan antara isu-isu tentang karbon dengan pengelolaan lahan gambut menjadi semakin penting dan telah menjadi pusat perhatian dunia. Hal ini berkaitan erat dengan peranan ekosistim gambut dalam perbaikan atau penurunan kualitas lingkungan global. Luas lahan gambut dunia hanya $3 \%$ dari luas permukaan bumi yakni sekitar 400 juta hektar (Joosten dan Clarke, 2002), namun menyimpan karbon yang sangat besar yakni diperkirakan sebanyak 550 Gton, atau setara dengan $75 \%$ dari seluruh karbon di atmosfir (Alex dan Joosten, 2008). Khusus untuk Indonesia, memiliki luas lahan gambut ketiga terluas di dunia setelah Rusia dan Canada yakni sekitar $265.500 \mathrm{~km}^{2}$, jumlah ini lebih dari setengah luas lahan gambut tropika (Joosten, 2009). Berdasarkan data kondisi tahun 2008, gambut Indonesia menyimpan karbon ke-tiga terbesar di dunia setelah Rusia dan Canada yakni 54.016 Mton (Joosten, 2009). Mengingat cadangan karbon yang besar pada lahan gambut sedangkan ekosistimnya sangat rapuh, maka apabila tidak dikelola dengan baik akan menyebabkan kehilangan karbon yang banyak, terutama dalam bentuk gas metan $\left(\mathrm{CH}_{4}\right)$ dan karbon dioksida $\left(\mathrm{CO}_{2}\right)$ ke atmosfir sehingga semakin meningkatkan emisi gas rumah kaca (GRK).

Meski memiliki fungsi strategis, konversi hutan gambut telah terjadi beberapa dekade terakhir dan masih terus berlangsung sampai sekarang. Sebagai gambaran, besarnya konversi lahan gambut dunia dapat dilihat dari laporan Alex dan Joosten (2008) yaitu 65 juta hektar luas 
lahan gambut dunia telah didrainase dan telah mengemisikan $\mathrm{CO}_{2}$ sebanyak 3 Gt per tahun. Khusus untuk Indonesia, selama periode 1985 - 2000 sebanyak $20 \%$ atau rata-rata sebesar $1,3 \%$ per tahun hutan gambut alami telah ditebang dan/atau dikonversi untuk penggunaan lain (Hooijer et al., 2006). Hal ini salah satunya adalah diperuntukkan untuk perluasan perkebunan kelapa sawit. Menurut data konsesi yang ada di Indonesia, menunjukkan bahwa $27 \%$ $\left(28.009 \mathrm{~km}^{2}\right)$ dari luas area konsesi untuk kelapa sawit berada pada lahan gambut (Hooijer et al., 2006). Untuk memproduksi 1 ton minyak sawit mengemisikan $10-30$ ton $\mathrm{CO}_{2}$ (Hooijer et al., 2006).

Tujuan penelitian ini adalah untuk mengestimasi jumlah cadangan, kehilangan, dan akumulasi karbon serta emisi gas rumah kaca $\left(\mathrm{CO}_{2}\right)$ pada perkebunan kelapa sawit di lahan gambut.

\section{METODE PENELITIAN}

Waktu dan Lokasi penelitian

Penelitian dilaksanakan pada bulan Mei 2008 sampai bulan Agustus 2009. Lokasi penelitian, pada perkebunan kelapa sawit rakyat di desa Suak Raya, kecamatan Johan Pahlawan dan desa Cot Gajah Mati, kecamatan Arongan Lambalek, Kabupaten Aceh Barat, serta desa Suak Puntong, kecamatan Kuala, Kabupaten Nagan Raya, Propinsi Nanggroe Aceh Darussalam.

Penelitian ini merupakan kegiatan pengamatan di lapangan (observational exploratory) yaitu melakukan diterminasi kasus pada lahan gambut yang didrainase untuk tanaman kelapa sawit dan analisa sampel tanah di laboratorium.. Sebanyak lima lokasi dengan perbedaan umur tanaman kelapa sawit dipilih sebagai tempat dilaksanakannya kajian, disajian dalam Tabel 1. Pengambilan data pada masingmasing areal kajian dilakukan dalam satu transek yang dibuat tegak lurus dengan saluran drainase. Pada masing-masing transek dilakukan pengamatan dan pengambilan sampel tanah di lima titik, yaitu mewakili lokasi dekat sampai jauh dari saluran drainase.

Pengamatan cadangan karbon

Untuk menduga cadangan karbon gambut diperlukan data Bulk Density (BD), kandungan karbon (\%C), dan ketebalan gambut. Ketebalan gambut diukur dengan cara menusukkan bor gambut ke dalam lapisan gambut hingga mencapai lapisan tanah mineral. Sampel tanah gambut diambil dengan bor gambut tipe setengah silinder (volume $500 \mathrm{~cm}^{3}$ ). Pengambilan sampel adalah pada setiap interval $50 \mathrm{~cm}$ peningkatan kedalaman lapisan gambut. Material gambut yang diambil dengan bor dimasukkan ke dalam kantong plastik untuk dianalisa di laboratorium nilai $\mathrm{BD}$, kadar abu dan kadar karbonnya.

BD dihitung dengan cara membagi berat tanah gambut kering dengan volumenya $\left(\mathrm{gr} \mathrm{cm}^{-3}\right)$. Kadar abu dan bahan organik, ditentukan dengan metoda Lost on Ignition (LOI). yaitu dengan cara membakar sekitar 2 gram sampel tanah gambut kering mutlak dalam tanur (furnace) pada suhu $550^{\circ} \mathrm{C}$ selama 6 jam. Berat bahan yang hilang ditetapkan sebagai total bahan organik, dan yang tersisa adalah kadar abu (bahan mineral). Untuk mengkonversi nilai bahan organik menjadi karbon biasanya digunakan konstanta 1,724 (Pribyl, 2010), namun dari hasil kajian ini nilai konsanta tersebut direvisi menjadi 1,9347. Konversi karbon menjadi $\mathrm{CO}_{2}$

Tabel 1. Lokasi penelitian berdasarkan umur tanaman kelapa sawit dan koordinat geografis No Kode Lokasi $\quad$ Umur tanaman $\quad$ Koordinat geografis (th)

\begin{tabular}{llcl}
\hline 1. & Desa Suak Raya I & 15 & $04^{0} 11^{\prime} 10^{\prime \prime}$ LU \& $096^{0} 07^{\prime} 02^{\prime \prime}$ BT \\
\hline 2. & Desa Suak Raya II & 15 & $04^{0} 11^{\prime} 09^{\prime \prime}$ LU \& $096^{0} 07^{\prime} 04^{\prime \prime}$ BT \\
\hline 3. & Desa Suak Puntong I & 10 & $04^{0} 06^{\prime} 20^{\prime \prime}$ LU \& $096^{0} 12^{\prime} 44^{\prime \prime}$ BT \\
\hline 4. & Desa Suak Puntong II & 10 & $04^{0} 06^{\prime} 24^{\prime \prime}$ LU \& $096^{0} 12^{\prime} 50^{\prime \prime}$ BT \\
\hline 5. & Desa Cot Gajah Mati & 1 & $04^{0} 22^{\prime} 53^{\prime \prime}$ LU \& $095^{0} 53^{\prime} 51^{\prime \prime}$ BT \\
\hline
\end{tabular}


digunakan faktor konversi 3,67, nilai ini berdasarkan perbandingan berat atom $\mathrm{CO}_{2}$ dengan atom $\mathrm{C}$ dalam senyawa $\mathrm{CO}_{2}$.

Untuk menentukan berat biomasa dan cadangan karbon yang tersimpan dalam vegetasi yang tumbuh diatas permukaan lahan gambut, ditentukan dengan cara mengukur berat biomasa dari vegetasi tersebut, menggunakan metoda yang dikemukakan oleh Hairiah dan Rahayu (2007). Khusus untuk biomasa dan karbon tersimpan dalam pohon kelapa sawit pada lahan gambut berdasarkan data dari hasil penelitian Yulianti (2009).

Pengukuran dalam muka air tanah: Pada masing-masing titik pengamatan pada lokasi terpilih, dipasang piezometer dari pipa paralon berdiameter 1 inchi yang dibenamkan secara vertikal kedalam tanah untuk monitoring tinggi muka air tanah.

Pengukuran subsidence: Untuk mengamati subsidence, pada masing-masing titik pengamatan dipasang tongkat dari besi yang ditancapkan ke dalam tanah sampai menembus lapisan tanah mineral, pada tongkat besi yang muncul dipermukaan tanah dibuat tanda permanen (titik awal pengamatan) untuk acuan dalam mengamati perubahan ketinggian permukaan tanah di sekitarnya.

Perhitungan kehilangan karbon: Peningkatan kadar abu (mineral) pada lapisan atas lahan gambut yang didrainase adalah berasal dari material gambut yang telah hilang bahan organiknya karena terdekomposisi. Bahan organik yang hilang akibat terdekomposisi dihitung berdasarkan peningkatan kadar abu yang dikemukakan oleh (Gronlund et al., 2008 dan Turetsky and Wieder, 2001).

Pengamatan dekomposisi biomasa: Biomasa berasal dari tumbuhan yang ada di kebun kelapa sawit yakni : a) pangkasan daun kelapa sawit Elaeis guinensis jag; b) Melastoma malabatricum dan c) Cycas sp, (istilah lokal = lampiding). Sebanyak 100 gram biomasa (berdasarkan berat kering mutlak) dimasukkan ke dalam kantong serasah (litter bag) dari bahan kasa nilon ukuran $35 \mathrm{~cm}$ x $35 \mathrm{~cm}$ dan ukuran lobang kasa $1 \mathrm{~mm}$. Kantong yang berisi biomasa diletakkan pada lapisan oksidasi lahan gambut, dan diamati kehilangan beratnya setelah periode waktu lebih kurang satu tahun.

\section{HASIL DAN PEMBAHASAN}

Cadangan Karbon

Hasil pengamatan dan perhitungan ketebalan gambut dan cadangan karbon yang tersimpan di dalamnya pada masing-masing lokasi disajikan pada Tabel 2. Distribusi karbon pada masing-masing lokasi yang diamati adalah: a) Kebun kelapa sawit umur 10 tahun di Suak Puntong I, 95,61\% pada tanah, 2,27\% pada pohon kelapa sawit dan 2,11\% pada gulma; b) Kebun kelapa sawit umur 10 tahun di desa Suak Puntong II, 95,88\% pada tanah, $2,32 \%$ pada kelapa sawit dan 1,80\% dalam biomasa gulma; c) Kebun kelapa sawit umur 15 tahun di desa Suak Raya I, 98,83\% dalam tanah, 0,76\% pada pohon kelapa sawit dan $0,41 \%$ dalam gulma; d) Kebun kelapa sawit umur 15 tahun di desa Suak Raya II, 96,91\% dalam tanah, 2,14\% dalam

Tabel 2. Rata-rata ketebalan gambut dan distribusi cadangan karbon pada perkebunan kelapa sawit di lahan gambut

\begin{tabular}{lcrrrr}
\hline \multicolumn{1}{c}{ Lokasi } & Ketebalan Gambut & \multicolumn{4}{c}{ Karbon $\left(\right.$ ton ha $\left.{ }^{-1}\right)$} \\
\cline { 3 - 6 } & \multicolumn{1}{c}{$\mathrm{cm})$} & Gambut & Semak & \multicolumn{1}{c}{ Pohon } & \multicolumn{1}{c}{ Total } \\
\hline Suak Puntong I & $126 \mathrm{c}$ & $606,5 \mathrm{~b}$ & 13,41 & 14,42 & 634,33 \\
Suak Puntong II & $118 \mathrm{c}$ & $596,6 \mathrm{~b}$ & 11,22 & 14,42 & 622,24 \\
Suak Raya I & $424 \mathrm{a}$ & $2108,9 \mathrm{a}$ & 8,77 & 16,26 & 2133,93 \\
Suak Raya II & $154 \mathrm{c}$ & $735,8 \mathrm{~b}$ & 7,22 & 16,26 & 759,28 \\
Cot Gajah Mati & $227 \mathrm{~b}$ & $677,9 \mathrm{~b}$ & 12,26 & 0,71 & 690,87 \\
\hline
\end{tabular}

Keterangan : Angka-angka yang diikuti oleh huruf kecil yang sama pada kolom yang sama tidak berbeda nyata pada selang kepercayaan $5 \%$ menurut LSD. 
pohon kelapa sawit, dan $0,95 \%$ dalam gulma; e) Kebun kelapa sawit umur 1 tahun di desa Cot Gajah Mati, 98,12\% dalam tanah, $1,77 \%$ dalam gulma, dan $0,10 \%$ dalam pohon kelapa sawit. Terlihat dari hasil kajian ini bahwa cadangan karbon yang tersimpan pada hamparan lahan gambut bervariasi berdasarkan ketebalan gambut dan umur tanaman. Yulianti (2009) menemukan cadangan karbon pada biomasa kelapa sawit pada lahan gambut bervariasi berdasarkan umur tanaman.

\section{Kehilangan Karbon}

Rata-rata subsidence, kedalaman muka air tanah maksimum, kehilangan karbon dan emisi gas rumah kaca, serta kontribusi kehilangan karbon terhadap subsidence disajikan dalam Tabel 3. Sedangkan hasil evaluasi pengukuran/estimasi kehilangan karbon berdasarkan metoda peningkatan kadar abu dibandingakn dengan pengukuran emisi gas $\mathrm{CO}_{2}$ secara langsung dengan metoda chamber disajikan dalam Tabel 4.

Hasil kajian menunjukkan bahwa. selama periode waktu 14 bulan terjadi kehilangan karbon dari lapisan permukaan gambut yang didrainase untuk perkebunan kelapa sawit, yang besarnya berkisar antara $0,138-1,529 \mathrm{~kg} \mathrm{C} \mathrm{m}^{-2}$. Berdasarkan hasil pengukuran selama periode waktu 14 bulan tersebut, apabila dikonversi menjadi data kehilangan karbon dalam periode satu tahun, diperoleh nilai rata-rata kehilangan karbon dari masing-masing lokasi kajian adalah berkisar antara $1,183-13,106$ ton $\mathrm{C} \mathrm{ha}^{-1} \mathrm{th}^{-1}$ atau setara dengan emisi gas $\mathrm{CO}_{2}$ sebesar 4,341-48,098 ton $\mathrm{CO}_{2} \mathrm{ha}^{-1} \mathrm{th}^{-1}$. (Tabel 3)

Kehilangan karbon terbanyak terjadi pada penggunaan lahan kelapa sawit umur 1 tahun di desa Cot Gajah Mati dan kelapa sawit umur 10 tahun di desa Suak Puntong. Hal ini diperkirakan terjadi karena pada kedua lokasi tersebut saluran drainase baru dibuat dan/atau diperbaharui (umur saluran $<2$ tahun) dibandingkan di desa Suak Raya (umur saluran > 10 tahun) sehingga lapisan permukaan gambut baru mengalami perobahan dari kondisi anaerobik manjadi aerobik, pada kondisi aerobik proses dekomposisi berlangsung sangat aktif sehingga menyebabkan kehilangan karbon dan/atau subsidence juga lebih besar. Dari data hasil pengamatan terlihat bahwa subsidence pada lokasi kebun kelapa sawit di desa Cot Gajah Mati dan desa Suak Puntong nyata lebih tinggi dibandingkan lokasi Suak Raya (Tabel 3). Hal ini sesuai dengan hasil penelitian Dawson et al. (2004) dan Gronlund et al. (2008) yang menemukan bahwa subsidence terbesar terjadi pada awal-awal saluran drainase dibuat.

Tabel 3. Rata-rata subsidence, dalam muka air tanah, kehilangan karbon dan prediksi emisi $\mathrm{CO}_{2}$ serta kontribusi kehilangan karbon terhadap subsidence..

\begin{tabular}{lcccccc}
\hline \multicolumn{1}{c}{ Lokasi } & $\begin{array}{c}\text { Subsi- } \\
\text { dence } \\
\text { (cm per } \\
\text { 14 bulan) }\end{array}$ & $\begin{array}{c}\text { Muka } \\
\text { air tanah } \\
\text { maksi- } \\
\text { mum } \\
(\mathrm{cm})\end{array}$ & $\begin{array}{c}\text { Karbon } \\
\text { hilang } \\
\mathrm{kg} \mathrm{m}^{-2} \\
\text { per } 14 \\
\text { bulan })\end{array}$ & $\begin{array}{c}\text { Karbon } \\
\text { hilang } \\
\left(\text { ton ha }^{-1}\right. \\
\left.\mathrm{th}^{-1}\right)\end{array}$ & $\begin{array}{c}\text { Setara } \\
\text { emisi } \\
\mathrm{CO}_{2} \\
\left(\text { ton ha }^{-}\right. \\
\left.\text {th }^{-1}\right)\end{array}$ & $\begin{array}{c}\text { Kontribusi } \\
\text { kehilangan } \\
\text { karbon } \\
\text { terhadap } \\
\text { subsidence } \\
(\%)\end{array}$ \\
\hline Cot Gajah Mati & $8,2 \mathrm{a}$ & 65,4 & $1,529 \mathrm{a}$ & 13,106 & 48,098 & 57,23 \\
Suak Puntong II & $9,2 \mathrm{a}$ & 86,4 & $1,292 \mathrm{ab}$ & 11,074 & 40,643 & 40,18 \\
Suak Puntong I & $8,2 \mathrm{a}$ & 73,4 & $1,236 \mathrm{ab}$ & 10,594 & 38,881 & 43,54 \\
Suak Raya I & $4,8 \mathrm{~b}$ & 58,0 & $0,802 \mathrm{c}$ & 6,874 & 25,229 & 52,07 \\
Suak Raya II & $1,1 \mathrm{c}$ & 52,8 & $0,138 \mathrm{~d}$ & 1,183 & 4,341 & 22,67 \\
\hline
\end{tabular}

Keterangan : Angka-angka yang diikuti oleh hurf kecil yang sama pada kolom yang sama tidak berbeda nyata pada selang kepercayaan 5\% menurut LSD. 
Tabel 4. Perbandingan hasil prediksi emisi $\mathrm{CO}_{2}$ antara pengukuran langsung dengan metoda chamber dan metoda peningkatan kadar abu.

\begin{tabular}{lcccccc}
\hline \multirow{2}{*}{ Lokasi } & \multicolumn{6}{c}{ Prediksi emisi $\mathrm{CO}_{2}\left(\mathrm{ton} \mathrm{ha}^{-1}\right.$ tahun $\left.^{-1}\right)$} \\
\cline { 2 - 7 } & Min & Mak & Rataan & Min & Mak & Rataan \\
\cline { 2 - 7 } & 0,145 & 70,085 & 23,328 & 21,243 & 30,873 & 25,229 \\
Suak Raya I & 3,866 & 29,881 & 13,767 & 1,983 & 5,098 & 4,341 \\
Suak Raya II & 1,265 & 28,427 & 18,320 & 18,411 & 67,695 & 38,881 \\
Suak Puntong I & 4,870 & 44,048 & 17,314 & 13,312 & 52,683 & 40,643 \\
Suak Puntong II & 8,464 & 100,592 & 41,169 & 34,272 & 59,481 & 48,098 \\
Cot Gajah Mati & &
\end{tabular}

Catatan: Sumber data emisi $\mathrm{CO}_{2}$ metoda chamber adalah Etik (2009)

Apabila dibandingkan antara nilai kehilangan karbon dan/atau emisi $\mathrm{CO}_{2}$ yang diprediksi dengan metoda peningkatan kadar abu dari hasil kajian ini dengan pengukuran $\mathrm{CO}_{2}$ secara langsung menggunakan metoda chamber, yang dilakukan oleh Etik (2009) pada lokasi dan periode waktu yang sama dengan kajian ini, hasilnya secara umum menunjukkan bahwa nilai emisi $\mathrm{CO}_{2}$ untuk setiap lokasi sama-sama terlihat beragam (interval nilai minimum dan maksimum lebar). Namun terlihat bahwa hasil prediksi emisi $\mathrm{CO}_{2}$ berdasarkan metoda peningkatan kadar abu, untuk setiap lokasi kajian berada dalam interval atau mendekati hasil pengukuran $\mathrm{CO}_{2}$ dengan metoda chamber (Tabel 4). Disamping itu pola emisi $\mathrm{CO}_{2}$ yang diperoleh juga sama yaitu semakin jauh dari saluran emisi/fluks $\mathrm{CO}_{2}$ semakin kecil. Hasil yang mirip dengan evaluasi pada kajian ini juga telah ditemukan oleh Gronlund et al. (2008) yang mana hasil pengujian terhadap tiga metoda untuk memprediksi emisi $\mathrm{CO}_{2}$ pada lahan gambut yang diolah di Norwegia yaitu: 1) monitoring subsidence dalam jangka panjang, 2) perubahan kadar abu, dan 3) pengukuran fluks $\mathrm{CO}_{2}$, hasilnya adalah nilai emisi $\mathrm{CO}_{2}$ antara ketiga metoda tersebut tidak berbeda nyata. Berdasarkan hal ini, dapat dikategorikan bahwa estimasi emisi $\mathrm{CO}_{2}$ dengan menggunakan data peningkatan kadar abu untuk gambut tropika dapat memberikan nilai yang representatif.
Keterkaitan antara muka air tanah, subsidence dan kehilangan karbon dengan jarak lokasi dari saluran drainase.

Hubungan antara dalam muka air tanah, subsidence dan kehilangan karbon dengan jarak tegak lurus lokasi dengan saluran drainase disajikan dalam Tabel 5 .

Hasil analisis hubungan antara dalam muka air tanah dengan jarak tegak lurus lokasi dari saluran drainase pada kajian ini, manunjukkan bahwa semakin dekat dengan saluran drainase muka air tanah lebih jauh dari permukaan tanah dan semakin jauh dari saluran drainase muka air tanah semakin dekat dengan permukaan tanah. Secara umum, pola transek dalam muka air tanah berdasarkan jarak lokasi tegak lurus dengan saluran drainase adalah mengikuti pola persamaan logaritmik. Pola seperti ini disebabkan oleh karena pada profil gambut pergerakan air arah horizontal menuju saluran drainase lebih cepat dibandingkan dengan pergerakan arah vertikal, sehingga pola transek dalam muka air tanah berdasarkan jarak tegak lurus dengan saluran drainase membentuk kemiringan (slopes) terhadap muka air pada saluran drainase (Susanne and Price 1999). Pola transek dalam muka air tanah pada kajian ini sejalan dengan hasil penelitian yang dilakukan oleh Finn (1983) yang mana dalam muka air tanah pada lahan yang didrainase, mengikuti pola logaritmik dengan jarak tegak lurus dari saluran.. Hasil penelitian Andrie et al. (2010) juga menemukan bahwa pembuatan saluran drainase yang berlebihan menyebabkan perubahan sifat-sifat fisika, kimia dan biologi gambut, dampaknya dalam muka air tanah pada musim kemarau letaknya jauh dari permukaan tanah, sedangkan pada 
musim hujan berada dekat permukaan tanah,

selain itu semakin dekat dengan saluran drainase dalam muka air

Tabel 5. Persamaan regresi hubungan antara dalam muka air tanah, subsidence dan kehilangan karbon pada sumbu (y) dengan jarak lokasi dari saluran drainase pada sumbu (x)

\begin{tabular}{|l|c|c|c|}
\hline \multirow{2}{*}{ Lokasi } & \multicolumn{3}{|c|}{ Persamaan regresi dan $\mathrm{R}^{2}$} \\
\cline { 2 - 4 } & Dalam muka air tanah & Subsidence & Kehilangan karbon \\
\hline Suak Raya I & $\mathrm{y}=6,63 \operatorname{Ln}(\mathrm{x})-86,10$ & $\mathrm{y}=-0,13 \operatorname{Ln}(\mathrm{x})+5,22$ & $\mathrm{y}=-0,01 \operatorname{Ln}(\mathrm{x})+0,92$ \\
& $\left(\mathrm{R}^{2}=0,65\right)$ & $\left(\mathrm{R}^{2}=0,02\right)$ & $\left(\mathrm{R}^{2}=0,003\right)$ \\
\hline Suak Raya II & $\mathrm{y}=34,50 \operatorname{Ln}(\mathrm{x})-72,67$ & $\mathrm{y}=-0,08 \operatorname{Ln}(\mathrm{x})+1,35$ & $\mathrm{y}=-0,02 \operatorname{Ln}(\mathrm{x})+0,17$ \\
& $\left(\mathrm{R}^{2}=0,94\right)$ & $\left(\mathrm{R}^{2}=0,14\right)$ & $\left(\mathrm{R}^{2}=0,21\right)$ \\
\hline Suak Puntong I & $\mathrm{y}=42,18 \operatorname{Ln}(\mathrm{x})-111,09$ & $\mathrm{y}=-3,78 \operatorname{Ln}(\mathrm{x})+20,66$ & $\mathrm{y}=-0,59 \operatorname{Ln}(\mathrm{x})+3,32$ \\
& $\left(\mathrm{R}^{2}=0,75\right)$ & $\left(\mathrm{R}^{2}=0,92\right)$ & $\left(\mathrm{R}^{2}=0,98\right)$ \\
\hline Suak Puntong II & $\mathrm{y}=50,36 \operatorname{Ln}(\mathrm{x})-142,90$ & $\mathrm{y}=-1,46 \operatorname{Ln}(\mathrm{x})+13,99$ & $\mathrm{y}=-0,25 \operatorname{Ln}(\mathrm{x})+2,27$ \\
& $\left(\mathrm{R}^{2}=0,97\right)$ & $\left(\mathrm{R}^{2}=0,19\right)$ & $\left(\mathrm{R}^{2}=0,33\right)$ \\
\hline Cot Gajah Mati & $\mathrm{y}=21,71 \operatorname{Ln}(\mathrm{x})-65,463)$ & $\mathrm{y}=-0,50 \operatorname{Ln}(\mathrm{x})+10,07$ & $\mathrm{y}=-0,19 \operatorname{Ln}(\mathrm{x})+2,43$ \\
& $\left(\mathrm{R}^{2}=0,98\right)$ & $\left(\mathrm{R}^{2}=0,57\right)$ & $\left(\mathrm{R}^{2}=0,66\right)$ \\
\hline
\end{tabular}

tanah letaknya jauh dari permukaan tanah dan semakin jauh dari saluran drainase dalam muka air tanah letaknya dekat dengan permukaan tanah.

Data hasil kajian secara umum mengindikasikan bahwa semakin dekat dari saluran drainase subsidence semakin besar dan semakin jauh dari saluran drainase subsidence semakin kecil. Terlihat bahwa pola transek subsidence, sejalan dengan pola transek dalam muka air tanah yang mana semakin dekat dari saluran drainase subsidence semakin besar juga mengikuti persamaan logaritmik. Hasil ini sesuai dengan beberapa hasil penelitian peneliti terdahulu seperti: Neil et al. (2005) mengemukakan pada posisi dekat dengan saluran drainase subsidence terjadi lebih banyak. Kondisi ini disebabkan oleh karena semakin dekat lokasi dengan saluran drainase muka air tanah lebih dalam dibandingkan dengan lokasi yang jauh dari saluran drainase, atau bagian gambut yang aerob lebih banyak pada lokasi yang dekat saluran dibandingkan yang jauh dari saluran. Pada kondisi seperti ini, aktivitas mikro organisme perombak dan proses dekomposisi yang terjadi juga lebih besar pada lokasi dekat saluran drainase dibandingkan yang jauh dari saluran, akibatnya material gambut yang hilang pada lokasi dekat saluran lebih banyak dibandingkan yang jauh dari saluran. Pada sisi lain, menurut Susanne and Price (1999) kondisi aerob menyebabkan tegangan matrik tanah meningkat sehingga gambut mengalami penyusutan (shrinkage), hal ini juga diperkirakan merupakan salah satu faktor yang menyebabkan subsidence pada lokasi yang dekat saluran drainase lebih besar dibandingkan yang jauh dari saluran drainase. Hasil kajian ini juga sejalan dengan hasil penelitian Etik (2009) yang mana pada lokasi yang sama dengan kajian ini beliau menemukan bahwa emisi $\mathrm{CO}_{2}$ secara umum meningkat dengan meningkatnya kedalaman muka air tanah, dan semakin jauh dari saluran drainase emisi $\mathrm{CO}_{2}$ semakin kecil.

Dari data yang ada yaitu: pola transek dalam muka air tanah, pola transek kejadian subsidence dan kehilangan karbon, mengindikasikan bahwa ada keterkaitan yang erat antara dalam muka air tanah, kehilangan karbon dan subsidence. Keterkaitan tersebut dapat dijelaskan sebagai berikut: Berdasarkan hasil kajian ditemukan bahwa semakin jauh dari saluran drainase dalam muka air tanah semakin dangkal, kondisi ini menyebabkan volume gambut yang berada dalam kondisi aerob lebih banyak pada lokasi dekat saluran drainase dibandingkan yang jauh dari saluran, sehingga aktivitas dekomposisi gambut karena proses oksidasi juga lebih banyak pada lokasi yang dekat saluran dibandingkan yang jauh dari saluran. Hal inilah yang menyebabkan fenomena subsidence dan kehilangan karbon juga semakin kecil dengan semakin jauhnya 
lokasi dari saluran drainase, karena material gambut yang hilang dan mengalami penyusutan pada lokasi dekat saluran drainase lebih banyak dibandingkan dengan lokasi yang jauh dari saluran.

Terlihat bahwa ditemukan ada anomali pola transek subsidence dan nilai kehilangan karbon pada penggunaan lahan kelapa sawit di desa Suak Raya I dibandingkan pola transek kehilangan karbon di lokasi lainnya. Anomali yang dimaksudkan adalah pola transek subsidence dan kehilangan karbon yang umum dari kajian ini adalah semakin jauh dari saluran drainase subsidence dan kehilangan karbon semakin kecil, namun pada lokasi kelapa sawit di desa Suak Raya I ada kecendrungan semakin jauh dari saluran drainase subsidence dan kehilangan karbon semakin besar. Hal ini terlihat dari, hasil analisa regresi terhadap data subsidence dan kehilangan karbon dengan jarak lokasi dari saluran adalah mengikuti pola model persamaan logaritmik $\left(R^{2}>0,2074\right)$, namun model persamaan logaritmik tersebut tidak dapat menjelaskan model fenomena subsidence dan kehilangan karbon pada penggunaan lahan kelapa sawit I di desa Suak Raya karena koefisien determinasi (R square) sangat kecil yaitu 0,02 dan 0,003 masing-masing untuk subsidence dan kehilangan karbon (Tabel 5).

Dari hasil komunikasi pribadi dengan pemilik lahan kelapa sawit I di desa Suak Raya yaitu Bapak H. Dahlan (Mei, 2008) diperoleh informasi bahwa beliau telah melakukan pemupukan pada kebun kelapa sawit dalam periode waktu yang lama, pupuk yang diaplikasikan adalah: urea, $\mathrm{KCl}$ dan SP36 yang diaplikasikan dua kali dalam setahun, dan pupuk posfat alam (istilah lokal $=$ pupuk asam) sekali dalam setahun. Sedangkan pada lokasi lain, berdasarkan hasil komunilasi pribadi dengan pemilik lahan, aparat desa, masyarakat umum diketahui bahwa pada lokasi tersebut tidak ada dilakukan pemupukan. Berkaitan dengan hal ini, berdasarkan keragaan kondisi di lapangan, terlihat bahwa pada penggunaan lahan kelapa sawit I di desa Suak Raya, populasi tanaman kelapa sawit pada bagian yang jauh dari saluran drainase lebih banyak (ada penyisipan tanaman kelapa sawit yang saat kajian ini dilaksanakan berumur sekitar
5 tahun) dibandingkan dengan yang dekat dari saluran, sehingga diperkirakan akumulasi pemberian pupuk per luasan yang sama pada area yang lebih jauh dari saluran drainase lebih banyak dibandingkan dengan yang dekat saluran drainase. Kenyataan ini dapat dijadikan sebagai dasar asumsi, bahwa pada penggunaan lahan kelapa sawit I di desa Suak Raya, dampak pemupukan terhadap kehilangan gambut dan subsidence lebih besar pada area lahan yang lebih jauh dari saluran drainase dibandingkan yang dekat saluran. Argumentasi ini sesuai dengan hasil penelitian Zhang et al. (2007) bahwa respirasi pada lahan yang dipupuk lebih tingi dari yang tidak dipupuk. Penelitian Etik (2009) pada gambut yang sama dengan kajian ini menunjukkan bahwa penambahan dosis pupuk urea menyebabkan penurunan bahan organik gambut dan peningkatan fluks $\mathrm{CO}_{2}$.

\section{Dekomposisi Biomasa}

Pola perubahan berat biomasa yang terjadi selama periode waktu 14 bulan proses dekomposisi berlangsung untuk masing masing spesies disajikan pada Tabel 6. Selanjutnya, kadar abu dan karbon yang diperlukan untuk mengestimasi kehilangan karbon dan emisi $\mathrm{CO}_{2}$ dari masing-masing biomasa sebelum dan sesudah proses dekomposisi serta hasil estimasi kehilangan karbon dan emisi gas $\mathrm{CO}_{2}$ dari masingmasing jenis biomasa disajikan dalam Tabel 7.

Terlihat bahwa setelah 14 bulan terdekomposisi, masih ada tersisa bahan tanaman yang tidak ikut terdekomposisi untuk semua jenis biomasa. Biomasa Cycas $\underline{\text { sp }}$ terlihat lebih tahan terhadap proses dekomposisi kemudian diikuti biomasa kelapa sawit (Elais guenensis jaq) dan Melastoma malabatrikum. Hal ini menunjukkan bahwa apabila biomasa tumbuhan dalam hal ini hasil pemangkasan daun kelapa sawit dan penyiangan gulma dikembalikan atau diupayakan tetap berada pada lahan masih berpotensi mengakumulasikan bahan gambut sebesar $12,45 \% ; 16,98 \%$ dan $74,57 \%$ dari total produksi biomasa yang dibiarkan tinggal pada permukaan lahan, 
Tabel 6. Pola dekomposisi masing-masing spesies biomasa

\begin{tabular}{|l|c|c|c|c|}
\hline \multirow{2}{*}{ Biomasa } & \multirow{2}{*}{ Rasio C/N } & \multicolumn{3}{|c|}{ Biomasa (\% atau gram) } \\
\cline { 3 - 5 } & & $\begin{array}{c}\text { Awal } \\
(0 \text { bulan })\end{array}$ & $\begin{array}{c}\text { Setelah 6 } \\
\text { bulan }\end{array}$ & $\begin{array}{c}\text { Setelah 14 } \\
\text { bulan }\end{array}$ \\
\hline Elais guenensis jaq & $23,04 \mathrm{c}$ & 100,00 & 54,75 & $16,93 \mathrm{~b}$ \\
\hline M elastoma malabatricum & $29,28 \mathrm{~b}$ & 100,00 & 40,36 & $12,45 \mathrm{c}$ \\
\hline Cycas sp & $42,88 \mathrm{a}$ & 100,00 & 98,91 & $74,57 \mathrm{a}$ \\
\hline
\end{tabular}

Keterangan: Angka-angka yang diikuti oleh hurf kecil yang sama pada kolom yang sama tidak berbeda nyata pada selang kepercayaan 5\% menurut LSD

masing-masing untuk Melastoma malabatrikum, Elais guenensis jaq, Cycas $\underline{\mathrm{sp}}$ secara berturut-turut (Tabel 6).

Data Tabel 6 menunjukkan bahwa setelah 14 bulan biomasa dikembalikan ke lahan masih ada material yang belum terdekomposi. Terlihat bahwa , untuk setiap kilo gram biomasa

selama periode waktu14, terjadi kehilangan atau emisi karbon sebesar 109,2 gr C; 464,0 gr $\mathrm{C}$ dan 470,2 gr $\mathrm{C}$ masing-masing untuk Cycas sp ; Elaeis guenensis jacg dan Melastoma malabatrikum secara berturutturut.

Apabila diasumsikan bahwa karbon yang hilang selama proses dekomposisi seluruhnya membentuk gas $\mathrm{CO}_{2}$, maka besarnya $\mathrm{CO}_{2}$ atau gas rumah kaca (GRK) yang diemisikan dari proses dekomposisi setiap $\mathrm{kg}$ biomasa per tahunnya adalah sekitar 343,4 $\mathrm{gr} \mathrm{CO}_{2} ; 1459,7$ gr $\mathrm{CO}_{2}$ dan 1479,3 gr $\mathrm{CO}_{2}$ masing-masing secara berurutan untuk biomasa Cycas $\underline{\mathrm{sp}}$; Elaeis guenensis jacg dan Melastoma malabatrikum .

Produksi biomasa pada perkebunan kelapa sawit di lahan gambut yang dapat dibiarkan tinggal di lahan dan berpotensi untuk menambah cadangan karbon disajikan pada Tabel 8.

Terlihat bahwa apabila biomasa hasil pangkasan daun kelapa sawit dan gulma dikumpulkan dan dibiarkan tetap berada di lahan perkebunan, maka karbon yang dikembalikan ke lahan setiap tahunnya adalah sekitar 9,39 ton C sampai 12,23 ton C per hektar per tahun (Tabel 8).

Apabila dikaitkan dengan hasil proses dekomposisi Tabel 6 dan Tabel 7, yang mana rata-rata biomasa pelepah kelapa sawit yang tersisa adalah sebanyak $16,93 \%$ dan rata-rata biomasa gulma yang tertinggal (biomasa M elastoma malabatricum + Cycas sp,) adalah 43,51\% maka dapat diprediksi total karbon bersih (net carbon) yang terakumulasi dari sisa dekomposisi biomasa yaitu sekitar 3,08 ton $\mathrm{C}$ sampai 4,77 ton $\mathrm{C}$ $\mathrm{ha}^{-1} \mathrm{th}^{-1}$. Adanya akumulasi karbon dari biomasa yang dikembalikan ke lahan, apabila besarnya dibandingkan dengan kehilangan karbon akibat dekomposisi gambut terlihat bahwa pada perkebunan kelapa sawit yang telah berumur 15 tahun di desa Suak Raya I (gambut dangkal) terjadi keseimbangan karbon yang positif (karbon yang terakumulasi lebih besar dari yang hilang).

Tabel 7. Berat abu dan karbon sebelum dan sesudah 14 bulan dekomposisi, serta estimasi kehilangan karbon dan emisi $\mathrm{CO}_{2}$.

\begin{tabular}{|l|c|c|c|c|c|c|c|}
\hline \multirow{2}{*}{ Biomasa } & \multicolumn{2}{|c|}{$\begin{array}{c}\text { Berat awal } \\
(\%)\end{array}$} & \multicolumn{2}{c|}{$\begin{array}{c}\text { Berat Akhir } \\
(\%)\end{array}$} & \multicolumn{2}{c|}{$\begin{array}{c}\text { Berat yang } \\
\text { hilang (\%) }\end{array}$} & \multirow{2}{*}{$\begin{array}{c}\mathrm{CO}_{2} \\
\left(\mathrm{gr} \mathrm{kg}^{-1}\right. \\
\text { biomasa) }\end{array}$} \\
\cline { 2 - 7 } & $\mathrm{Abu}$ & $\mathrm{C}$ & $\mathrm{Abu}$ & $\mathrm{C}$ & $\mathrm{Abu}$ & $\mathrm{C}$ & \\
\hline Elaeis guenensis jag & 4,36 & 55,48 & 1,29 & 9,07 & 3,07 & 46,40 & 170,30 \\
\hline M elastoma malabatrikum & 7,97 & 53,38 & 1,49 & 6,36 & 6,48 & 47,02 & 172,58 \\
\hline Cycas sp & 9,31 & 52,60 & 2,70 & 41,69 & 6,61 & 10,92 & 40,06 \\
\hline
\end{tabular}


Tabel 8. Potensi biomasa yang dapat dikembalikan pada lahan di perkebunan kelapa sawit di lahan gambut

\begin{tabular}{|c|c|c|}
\hline \multirow[b]{2}{*}{ Jenis Biomasa } & \multicolumn{2}{|c|}{ Produksi Biomasa } \\
\hline & $\begin{array}{l}\text { Biomasa kering oven } \\
\quad\left(\text { ton } \mathrm{ha}^{-1} \mathrm{th}^{-1}\right)\end{array}$ & $\begin{array}{r}\text { Setara karbon } \\
\left.\text { (ton ha } \mathrm{ha}^{-1} \text { th }^{-1}\right)\end{array}$ \\
\hline Pelepah dan daun sawit & $2,53-3,35$ & $1,40-1,86$ \\
\hline $\begin{array}{l}\text { Biomasa penyiangan } \\
\text { (M elastoma malabatricum }+ \\
\text { Cycas sp, dll) }\end{array}$ & $14,94-19,39$ & $7,99-10,37$ \\
\hline Total & $17,47-22,74$ & $9,39-12,23$ \\
\hline
\end{tabular}

\section{KESIMPULAN DAN SARAN}

Kesimpulan

Karbon tersimpan pada perkebunan kelapa sawit di lahan gambut bervariasi berdasarkan ketebalan gambut dan umur tanaman. Jarak lokasi dari saluran drainase berpengaruh terhadap dalam muka air tanah, subsidence, dan kehilangan karbon, yang mana semakin jauh dari saluran drainase: muka air tanah semakin dangkal (dekat permukaan), subsidence semakin kecil, dan kehilangan karbon semakin kecil. Kehilangan karbon dan subsidence pada perkebunan kelapa sawit di lahan gambut, bervariasi berdasarkan umur saluran. Kejadian subsidence pada perkebunan kelapa sawit di lahan gambut sekitar 22,67 - 57,23\% disebabkan oleh kehilangan karbon. Metoda baru yang dapat digunakan untuk mengestimasi kehilangan karbon dan/atau emisi $\mathrm{CO} 2$ adalah "peningkatan kadar abu". Membiarkan biomasa sisa tanaman tetap berada di lahan pada perkebunan kelapa sawit di lahan gambut berpotensi mengakumulasikan karbon pada lahan gambut sekitar 3,08 ton C sampai 4,77 ton $\mathrm{C} \mathrm{ha}^{-1} \mathrm{th}^{-1}$. Besar atau kecilnya karbon yang dapat diakumulasikan dari biomasa dipengaruhi oleh rasio $\mathrm{C} / \mathrm{N}$ biomasa. semakin tinggi nilai rasio $\mathrm{C} / \mathrm{N}$ biomasa semakin banyak karbon yang dapat diakumulasikan. Data hasil kajian menunjukkan bahwa emisi karbon dapat dikontrol pada perkebunan kelapa sawit di lahan gambut dangkal (ketebalan $\pm 1 \mathrm{~m}$ ).

\section{Saran}

Dalam muka air tanah mempengaruhi subsidence dan kehilangan karbon, untuk itu dalam pengelolaan lahan gambut yang telah didrainase dan/atau dikonversi menjadi perkebunan kelapa sawit, yang penting diperhatikan adalah teknik pengaturan tinggi muka air tanah sehingga dapat mereduksi dan/atau memitigasi kehilangan karbon. Perkebunan kelapa sawit di lahan gambut disarankan hanya pada gambut dangkal.

\section{DAFTAR PUSTAKA}

Alex K and Joosten H. 2008. Global peatland assesment. Factbook for UNFCCC policies on peat carbon emission.

Andrie E. 2010. The depth of ground water table dynamics and charackteristic of peatland near drainage canal ex, mega rice project in CentralKalimantan. Makalah Seminar Ilmiah VI Lingkungan Tropis IATPI.

Dawson, J.J.C., Billett, M.F., Hope, D., Palmer, S.M. and Deacon, C. 2004. Sources and sinks of aquatic carbon linked to a peatland stream continuum. Biogeochemistry 70: 7192.

Etik, P.H. 2009. Emisi karbon dioksida (CO2) dan metan (CH4) pada perkebunan kelapa sawit di lahan gambut yang memiliki keragaman dalam ketebalan gambut dan umur tanaman. Disertasi S.3. Program Studi Ilmu Tanah, Sekolah Pascasarjana, Institut Pertanian Bogor. 158 hal.

Finn H. B. 1983. Water table levels at different drainage intensities on deep peat in Northern Norway. 
Forest Ecology and Management Volume 5, Issue 3: 169-192

Gronlund, A., Atle H., Anders, H. and Daniel, P.R.2008. Carbon loss estimates from cultivated peat soils in Norway: a comparison of three methods. Nutr Cycl Agroecosyst. 81: $157-167$.

Hairiah, K. dan Rahayu, S. 2007. Petunjuk praktis pengukuran "karbon tersimpan" di berbagai macam penggunaan lahan. World Agroforestry Centre. 77 hal.

Hooijer A, Silvius M, Wösten H, Page S. 2006. PEAT $\mathrm{CO}_{2}$, Assessment of $\mathrm{CO}_{2}$ Emission from drained peatlands in SE Asia. Wetland International and Delft Hydraulics report Q3943.

Joosten H, and Clarke D. 2002. Wise use of mires and peatlands - Background and principles including a framework for decision-making. International Mire Conservation Group / International Peat Society, 304pp.

Joosten H. 2009. Peatland status and drainage related emissions in all countries of the world. The Global Peatland $\mathrm{CO} 2$ Picture. Wetlands International. www.wetlands.org. $35 \mathrm{p}$.

Neil F, Sarah B and Malcolm McL. 2005. Peat subsidence near drains in the Waikato region. Environment Waikato Technical Repot 2005/40. 33p.

Pribyl. 2010. A critical review of the conventional SOC to SOM conversion factor. Geoderma. 196: $75-83$.

Susanne, M.S. and Price, J.S. 1999. Soil water flow dynamics in managed cutover peat field, Quebec: Field and laboratory invertigations. Water Resouces Research. Vol. 35. No. 12: 3675-3683.
Turetsky, M.R. and Wieder, R.K. 2001. A direct approach to quantifying organic matter lost as a result of peatland wildfire. Can. J. For. Res. 31: 363-366.

Yulianti N. 2009. Cadangan karbon lahan gambut dari agroekosistem kelapa sawit PTPN IV Ajamu Kabupaten Labuhan Batu, Sumatera Utara. Tesis Sekolah Pasca Sarjana IPB Bogor.

Zhang. 2007. Effects of nitrogen on the ecosystem respiration, $\mathrm{CH} 4$ and $\mathrm{N}_{2} \mathrm{O}$ emissions to the atmosphere from the freshwater marshes in Northeast China. Environ Geol. 52: 529-539. 